\title{
Meningkatkan Kemampuan Guru BK SMA dalam Pelaksanaan LayananBimbingan Klasikal Melalui Supervisi Klinis
}

\author{
Gusti Nyoman Astika ${ }^{1^{*}}$ \\ ${ }^{1}$ Pengawas BK Dikmen Dinas Pendidikan, Kepemudaan dan Olahraga Provinsi Bali, \\ *Corresponding author, e-mail: gusti.nyoman.astika@gmail.com
}

Received January 12th , 2021; Revised Month February 1st, 2021;

Accepted March 15, 2021; Published Online March 20, 2021

\section{Conflict of Interest} Disclosures:

The authors declare that they have no significant competing financial, professional or personal interests that might have influenced the performance or presentation of the work described in this manuscript.

\begin{abstract}
This study aims to determine whether clinical supervision can improve the ability of BK teachers (school counselor) at senior high school in Buleleng Regency in implementing classical guidance services. This type of research is an action research which is carried out in 2 (two) cycles. Each cycle consists of four stages, namely planning the action, implementing the action, observing, and reflecting. The research subjects were 12 counselor at senior high school in Buleleng Regency, which were determined based on the results of re-cycle observations. The data was collected by observational techniques using classical guidance service assessment instruments, which were then analyzed using quantitative descriptive analysis. The results obtained from this study stated that the acquisition of the initial ability of teachers in implementing classical guidance services obtained an average of 59.52 (moderate category) to 77.68 (good category) in cycle I, and increased to 85.42 (good category). ) in cycle II. The conclusion obtained from this research is that clinical supervision can improve the ability of school counselor at senior high school in Buleleng Regency in implementing classical guidance services.
\end{abstract}

Keywords: Classical guidance and counseling service, Clinical supervision.

Indonesian Abstract. Penelitian ini bertujuan untuk mengetahui apakah supervisi klinis dapat meningkatkan kemampuan guru BK SMA Negeri di Kabupaten Buleleng dalam pelaksanaan layanan bimbingan klasikal. Jenis penelitian ini adalah penelitian tindakan sekolah (PTS) yang dilaksanakan dalam 2 (dua) siklus. Masing-masing siklus terdiri dari empat tahapan yaitu perencanaan tindakan, pelaksanaan tindakan, observasi, dan refleksi. Subjek penelitian adalah guru-guru BK SMA Negeri di Kabupaten Buleleng yang berjumlah 12 orang, yang ditentukan berdasarkan hasil observasi pada pra siklus. Pengumpulan data dilakukan dengan teknik observasi menggunakan instrumen penilaian layanan bimbingan klasikal, yang selanjutnya data tersebut dianalisis dengan analisis deskriptif kuantitatif. Hasil yang diperoleh dari penelitian ini menyatakan bahwa perolehan nilai kemampuan awal guru dalam melaksanakan layanan bimbingan klasikal diperoleh rata-rata 59,52 (kategori sedang) menjadi 77,68 (kategori baik) di siklus I, dan meningkat menjadi 85,42 (kategori baik) di siklus II. Simpulan yang diperoleh dari penelitian ini bahwa supervisi klinis dapat meningkatkan kemampuan guru BK SMA Negeri di Kabupaten Buleleng dalam melaksanakan layanan bimbingan klasikal.

Kata Kunci: Layanan Bimbingan Klasikal, Supervisi Klinis

How to Cite: Gusti Nyoman Astika. 2021. Meningkatkan Kemampuan Guru BK SMA Negeri Di Kabupaten Buleleng Dalam Pelaksanaan Layanan Bimbingan Klasikal Melalui Supervisi Klinis . JIBK Undiksha, 12 (1): pp.64-72. DOI: http://dx.doi.org/10.23887/xxxx 


\section{Pendahuluan}

Undang-undang RI No. 20 Tahun 2003 tentang Sistem Pendidikan Nasional pasal 4 menyatakan Pendidikan Nasional bertujuan mencerdaskan kehidupan bangsa dan mengembangkan manusia Indonesia seutuhnya, yaitu manusia yang beriman dan bertakwa terhadap Tuhan Yang Maha Esa dan berbudi pekerti luhur, memiliki pengetahuan dan keterampilan, kesehatan jasmani dan rohani, kepribadian yang mantap dan mandiri serta rasa tanggung jawab kemasyarakatan dan kebangsaan. Pencapaian tujuan satuan pendidikan tersebut diaktualisasikan guru dalam proses pembelajaran sesuai dengan amanah Permendiknas Nomor 41 Tahun 2007 tentang Standar Proses. Guru adalah salah satu komponen paling penting dalam upaya pencapaian tujuan pendidikan karena guru merupakan ujung tombak pelaksanaan suatu program pendidikan yang dilakukan pada kegiatan pembelajaran di kelas.

Usman (1995), menyatakan bahwa "kegiatan pembelajaran yang kondusif, dan pelaksanaan bimbingan yang terarah pada peserta didik, merupakan komponen penting yang harus dilaksanakan dalam rangka pencapaian tujuan sekolah. Sekolah yang kondusif adalah sekolah yang melaksanakan program bimbingan konseling dengan baik". Bimbingan dan Konseling (BK) merupakan kegiatan yang terintegrasi dalam kegiatan pendidikan di sekolah, merupakan bentuk layanan yang muncul dalam proses pendidikan sebagai usaha intervensi dengan tujuan membantu peserta didik agar dapat mencapai tujuan pendidikan, mampu menentukan pilihan, dan bertanggung jawab terhadap diri sendiri, keluarga, masyarakat, serta dalam hubungannya secara vertikal dengan Tuhan.

Orientasi bantuan layanan BK tidak terbatas pada usaha membantu peserta didik di saat mengalami masalah saja, tetapi lebih berorientasi pada pemahaman, pencegahan, dan juga pengembangan dan pemeliharaan. Layanan BK memiliki berbagai setting pelayanan, diantaranya bimbingan dalam setting klasikal dan bimbingan dalam setting kelompok. Melalui bimbingan klasikal, guru BK dapat memberikan layanan bimbingan kepada sejumlah peserta didik dengan waktu yang lebih efisien. Dalam Permendikbud No. 111 tahun 2014 dinyatakan "Layanan bimbingan dan konseling di dalam kelas (bimbingan klasikal) merupakan layanan yang dilaksanakan dalam setting kelas, diberikan kepada semua peserta didik, dalam bentuk tatap muka terjadwal dan rutin setiap kelas/per minggu". Dalam Rosidah (2017), dinyatakan bahwa layanan bimbingan klasikal adalah salah satu pelayanan dasar bimbingan yang dirancang menuntut konselor untuk melakukan kontak langsung dengan para peserta didik secara terjadwal, berupa kegiatan diskusi kelas, tanya jawab, dan praktik langsung yang dapat membuat peserta didik aktif dan kreatif dalam mengikuti kegiatan yang diberikan.

Berkembangnya strategi dan pendekatan dalam pelaksanaan layanan BK harus diikuti dengan perkembangan kemampuan guru BK. Guru BK harus melakukan inovasi agar pelaksanaan layanan bimbingan klasikal berjalan efektif dan berkembang sesuai kebutuhan. Layanan bimbingan klasikal seharusnya diselenggarakan secara interaktif, inspiratif dalam suasana yang menyenangkan, menggairahkan, menantang, memotivasi peserta didik untuk berpartisipasi aktif, serta memberikan ruang yang cukup bagi prakarsa, kreativitas, dan kemandirian sesuai dengan bakat, minat, dan perkembangan fisik serta psikologis peserta didik.

Dari hasil pemantauan dan penilaian peneliti selaku pengawas BK dalam melaksanakan kegiatan kepengawasan, masih ditemukan beberapa guru BK SMA Negeri di kabupaten Buleleng belum mampu menerapkan layanan bimbingan klasikal yang inovatif. Guru BK kurang mengembangkan proses pelaksanaan layanan bimbingan klasikal, guru BK masih dominan menggunakan metode ceramah di kelas. Dominannya guru BK menggunakan metode ceramah dalam kegiatan layanan bimbingan klasikal diduga menjadi salah satu penyebab kurangnya minat dan antusias peserta didik dalam mengikuti layanan bimbingan klasikal dan tidak tercapainya perubahan sikap dari peserta didik khususnya pada perubahan tingkah laku. Alasan-alasan klasik yang disampaikan oleh guru BK yaitu karena tidak tersedianya waktu masuk kelas secara terjadwal. Guru BK membutuhkan bantuan profesional untuk meningkatkan kualitas layanan klasikal agar dapat mengetahui, memahami kelebihan dan kelemahan di bidang keterampilan layanan klasikal guna selanjutnya berusaha meningkatkannya ke arah yang lebih baik lagi.

Peningkatan profesionalisme guru BK menjadi tanggung jawab guru BK, pengawas BK dan kepala sekolah sebagai mitra kerja. Kepala sekolah dan pengawas BK sebagai supervisor mempunyai tugas, wewenang serta tanggung jawab untuk memberikan layanan pembelajaran kepada guru. Dalam Peraturan Menteri Pendidikan Nasional Republik Indonesia Nomor 12 Tahun 2007, menyebutkan tugas pengawas adalah "membimbing guru dalam melaksanakan kegiatan pembelajaran/bimbingan (di kelas, laboratorium, dan atau di lapangan) untuk tiap mata pelajaran dalam rumpun mata pelajaran yang relevan di sekolah menengah yang sejenis". 
Hal ini mendorong peneliti melakukan perbaikan proses layanan bimbingan klasikal, memperbaiki/meningkatkan kemampuan guru BK dalam mengelola kelas, meningkatkan kemampuan guru BK dalam menggunakan metode dan model pembimbingan yang lebih inovatif dalam proses layanan bimbingan klasikal. Salah satu upaya pembinaan yang dilakukan peneliti untuk meningkatkan kemampuan guru BK dalam proses layanan bimbingan klasikal melalui model supervisi klinis. Supervisi klinis merupakan bagian dari supervisi pengajaran, prosedur pelaksanaan supervisi klinis ditekankan untuk mencari sebab akibat atas kelemahan yang terjadi di dalam proses belajar mengajar, cara memberikan obatnya dilakukan setelah supervisor mengadakan observasi secara langsung terhadap perilaku mengajar guru di kelas, kemudian diskusi balikan secara terbuka segera setelah guru selesai mengajar dengan harapan agar kelemahan yang dilakukan guru selama mengajar dapat segera diketahui dan bagaimana usaha untuk memperbaikinya segera teratasi.

Cogan (1973: 54) dalam Depdiknas (2008: 34), supervisi klinik didefinisikan sebagai berikut: "The rational and practice designed to improve the teacher supervisi classroom performance. It takes its principal data from the events of the classroom. The analysis of these data and the relationships between teacher and supervisor from the basis of the program, procedures, and strategies designed to improve the student' supervisi learning by improving the teacher's supervisi classroom behavior". Sesuai dengan pendapat Cogan ini, bahwa supervisi klinis pada dasarnya merupakan pembinaan performansi guru mengelola proses belajar mengajar. Pelaksanaannya di desain dengan praktis secara rasional. Baik desainnya maupun pelaksanaannya dilakukan atas dasar analisis data mengenai kegiatan - kegiatan di kelas. Data dan hubungan antara guru dan supervisor merupakan dasar program prosedur, dan strategi pembinaan perilaku mengajar guru dalam mengembangkan belajar murid-murid.

Suaidinmath (2010), menggungkapkan bahwa secara umum supervisi klinis diartikan sebagai bentuk bimbingan profesional yang diberikan kepada guru berdasarkan kebutuhannnya melalui siklus yang sistematis. Siklus sistematis ini meliputi: perencanaan, observasi yang cermat atas pelaksanaan dan pengkajian hasil observasi dengan segera dan obyektif tentang penampilan mengajarnya yang nyata. Selanjutnya dalam Danim dan Khairil (2011: 179), dikemukakan bahwa supervisi klinis adalah bantuan profesional oleh supervisor kepada guru yang mengalami masalah dalam pembelajaran agar yang bersangkutan atau guru dapat mengatasi masalahnya dengan menempuh langkah yang sistematis, dimulai dari tahap perencanaan, pengamatan perilaku guru mengajar, analisis perilaku, dan tindak lanjut.

Dari paparan yang telah diuraikan di atas, dapat disintesiskan bahwa supervisi klinis adalah suatu bentuk kegiatan pembinaan, arahan, atau bimbingan yang dilakukan oleh supervisor kepada guru yang lemah atau yang memiliki masalah dalam mengelola proses pembelajaran/pembimbingan melalui proses siklus yang sistematis dengan tujuan untuk memperbaiki atau meningkatkan kompetensi dan keterampilan guru dalam mengelola proses belajar mengajar dan sikap profesionalnya.

Supervisi klinis bertujuan untuk menjamin kualitas pelayanan belajar secara berkelanjutan dan konsisten. Masaong (2013: 55), mengungkapkan bahwa "supervisi klinis bertujuan untuk memperbaiki performance guru dalam proses pembelajaran dan membantu siswa dalam mengatasi masalah-masalah pembelajaran secara efektif'. Dalam upaya pencapaian tujuan supervisi klinis, diperlukan langkah-langkah proses pelaksanaan supervisi klinis. Sahertian (2008), memberikan tiga tahapan dalam pelaksanaan supervisi klinis sebagai berikut. Pertama, dalam percakapan awal ini seorang guru mengeluh bahwa pada saat melaksanakan tugas mengajar di kelas menemui kendala yang sulit dipecahkan sendiri. Kedua, tahap kedua observasi. Pada tahap ini supervisor menggunakan alat observasi check list kemudian diadakan analisis dari hasil observasi tersebut. Ketiga, tahap ketiga merupakan kegiatan akhir, yaitu percakapan yang dilaksanakan setelah analisis dilakukan percakapan ini terjadi antara supervisor dengan guru. Dalam percakapan ini akan terungkap bahwa memang terjadi sesuatu permasalahan yang dihadapi guru dalam kelas.

Bertitik tolak dari uraian di atas, maka masalah pokok yang ingin dicari jawabannya melalui penelitian tindakan sekolah ini adalah apakah supervisi klinis dapat meningkatkan kemampuan guru BK SMA Negeri di Kabupaten Buleleng dalam pelaksanaan layanan bimbingan klasikal.

Adapun tujuan penelitian ini adalah untuk meningkatkan kemampuan guru BK SMA Negeri di kabupaten Buleleng dalam pelaksanaan layanan bimbingan klasikal melalui supervisi klinis. Sedangkan manfaat yang diharapkan dari aspek teoritis, bahwa hasil penelitian ini diharapkan dapat dijadikan referensi dalam mengembangkan pengetahuan tentang upaya meningkatkan kemampuan guru BK dalam pelaksanaan layanan bimbingan klasikal melalui supervisi klinis. Sedangkan dari aspek praktis diharapkan dapat bermanfaat: 1) bagi guru BK, sebagai refleksi diri sehingga dapat meningkatkan pemahaman dan keterampilannya dalam pelaksanaan layanan bimbingan klasikal; 2) bagi kepala sekolah, sebagai umpan balik guna perbaikan kualitas guru BK, sehingga terjadi peningkatan kualitas layanan BK; 3) bagi pengawas 
BK, sebagai bahan informasi tentang kondisi riil yang ada di lapangan dalam upaya peningkatan kompetensi guru BK; dan 4) bagi Kepala Dinas Pendidikan Provinsi Bali, diharapkan hasil penelitian ini menjadi masukan yang berharga dalam pengambilan kebijakan terkait dengan pemberdayaan guru, serta dapat memberi kontribusi dalam peningkatan kualitas pelaksanaan layanan BK.

\section{Metode}

Jenis penelitian ini adalah penelitian tindakan sekolah (PTS) yaitu penelitian tindakan yang terdiri dari siklus-siklus, menggunakan rancangan penelitian tindakan yang disampaikan oleh Suharsimi Arikunto, dkk (2006) dengan dua siklus yang masing-masing siklus terdapat 4 tahapan yang lazim dilalui yaitu: (1) Perencanaan, (2) Pelaksanaan, (3) Pengamatan, dan (4) Refleksi. Subjek penelitian ini adalah guru-guru BK SMA Negeri di Kabupaten Buleleng yang berjumlah 12 orang. Penelitian dilaksanakan selama 4 bulan dimulai bulan Juli 2019 sampai dengan bulan Oktober 2019 bertempat di beberapa SMA Negeri wilayah binaan di Kabupaten Buleleng.

Pada tahap perencanaan tindakan, dilaksanakan kegiatan menyusun skenario tindakan atau menyusun Rencana Kepengawasan Akademik, menyiapkan instrumen observasi kelas (Instrumen Penilaian Layanan Klasikal), dan menyusun jadwal supervisi. Pada tahap pelaksanaan tindakan, dilakukan kegiatan sesuai dengan jadwal dan rencana tindakan penelitian yang telah ditentukan dalam skenario tindakan. Selama kegiatan layanan klasikal berlangsung, dilakukan kegiatan pengamatan yang bertujuan untuk mengumpulkan data tentang kemampuan guru dalam melaksanakan layanan klasikal. Begitu pula studi dokumen dilakukan dalam rangka penilaian masing-masing RPL klasikal yang dipergunakan guru dalam melakukan layanan, sekaligus membuat catatan tentang hal-hal yang perlu diperbaiki serta mencatat hasil wawancara dengan guru. Pada tahap keempat yaitu kegiatan refleksi, yang dimaksudkan untuk mengkaji secara menyeluruh tindakan yang telah dilakukan didasarkan atas data yang diperoleh melalui observasi kelas, hasil wawancara maupun hasil pengamatan dokumen RPL untuk kemudian dilakukan review hasil hasil yang dicapai, serta menganalisis/mengkaji usaha dan rencana perbaikan pada siklus berikutnya, sampai masalah yang diteliti dapat dipecahkan secara optimal.

Metode dan alat yang dipergunakan untuk mengumpulkan data penelitian ini adalah observasi, studi dokumen dan wawancara. Metode observasi dilaksanakan dengan cara mengamati kegiatan guru BK dalam layanan klasikal, menggunakan instrumen penilaian layanan klasikal. Studi dokumen pada penelitian ini menggunakan instrumen penilaian RPL untuk mengetahui kemampuan guru dalam menyusun rencana program pelayanan, sedangkan metode wawancara dipergunakan untuk melengkapi pembahasan hasil penelitian.

Setelah data dalam penelitian ini terkumpul maka selanjutnya dilakukan analisis data. Data kemampuan guru dalam melaksanakan layanan bimbingan klasikal dianalisis menggunakan analisis statistik deskriptif dengan menggunakan Microsoft Office Excel 2007. Untuk data kualitatif dianalisis dengan memberi pertimbangan-pertimbangan, memberi komentar-komentar, dan menyampaikan perubahan-perubahan yang pada akhirnya dicari maknanya sebagai kesimpulan refleksi dengan mencari makna dari kesimpulan hubungan antar kategori.

Untuk data kuantitatif dianalisis dengan menghitung perolehan nilai masing-masing guru BK. Penilaian menggunakan skor 0,1 , dan 2 sesuai format lembar penilaian layanan bimbingan klasikal. Dari skor yang diperoleh, kemudian dicari nilai kuantitatifnya dengan rumus sebagai berikut.

Nilai Kuantitatif $=\frac{\text { Jumlah skor }}{\text { Jumlah skor maksimal }} \times 100$

Nilai Kuantitatif kemudian diklasifikasikan/dikategorikan ke dalam nilai dan sebutan seperti pada tabel 1 berikut.

Tabel 1. <Kategori Hasil Penilaian>

\begin{tabular}{ll}
\hline Nilai & Kategori \\
& \\
\hline $91-100$ & Amat Baik \\
$76-90$ & Baik \\
$61-75$ & Cukup \\
$51-90$ & Baik \\
$\leq 50$ & Kurang \\
\hline
\end{tabular}

(Permenpan dan RB No. 16 tahun 2009: 12). 
Selanjutnya dipresentasikan berapa jumlah guru BK yang memiliki kemampuan dalam melaksanakan layanan bimbingan klasikal ke dalam kategori kurang, sedang, cukup, baik, dan amat baik. Kemudian dihitung nilai rata-ratanya. Kegiatan penelitian ini dikatakan berhasil jika terjadi peningkatan kemampuan guru BK dalam melaksanakan layanan bimbingan klasikal, dengan indikator kinerja yakni (1) 100\% guru BK memperoleh nilai kategori Baik (76 - 90) dan (2) Nilai rata-rata sekurang-kurangnya 85 (kategori Baik).

\section{Hasil dan Pembahasan}

Berdasarkan hasil temuan awal kemampuan guru BK dalam pelaksanaan layanan bimbingan klasikal terdapat 5 orang guru $(41,67 \%)$ mendapat nilai $\leq 60$ (kategori sedang) dan 7 orang guru $(58,33 \%)$ mendapat nilai $\leq 75$ (kategori cukup), dengan nilai kemampuan rata-rata 59,52 (kategori sedang). Untuk lebih jelas dapat dilihat pada tabel 2 .

Ditemukan pada indikator penilaian komponen perencanaan, bahwa pada instrumen penilaian hasil belum mengacu pada tujuan yang akan dicapai. Guru BK kurang mampu mengelola kelas, sehingga tidak tercipta suasana yang kondusif. Pada kegiatan penutup, guru BK lupa untuk merangkum atau membuat kesimpulan inti dari kegiatan bimbingan.

Tabel 2. <Nilai Kemampuan Awal Guru BK dalam Pelaksanaan Layanan Bimbingan Klasikal>

\begin{tabular}{llll}
\hline No & Nama Guru BK & Perolehan Nilai Kuantitatif & $\begin{array}{l}\text { Klasifika } \\
\text { si }\end{array}$ \\
$\mathbf{1}$ & NKNY & 57 & Sedang \\
$\mathbf{2}$ & NKJA & 61 & Cukup \\
$\mathbf{3}$ & KJS & 61 & Cukup \\
$\mathbf{4}$ & NS & 57 & Sedang \\
$\mathbf{5}$ & KS & 64 & Cukup \\
$\mathbf{6}$ & KNH & 57 & Sedang \\
$\mathbf{7}$ & INT & 61 & Cukup \\
$\mathbf{8}$ & NPK & 57 & Sedang \\
$\mathbf{9}$ & NKSA & 61 & Cukup \\
$\mathbf{1 0}$ & NKAY & 57 & Sedang \\
$\mathbf{1 1}$ & IKS & 61 & Cukup \\
$\mathbf{1 2}$ & WR & 61 & Cukup \\
& Jumlah & $\mathbf{7 1 4}$ & \\
& Rata-rata & $\mathbf{5 9 , 5 2}$ & Sedang \\
\hline
\end{tabular}

Upaya peningkatan dilakukan melalui kegiatan supervisi klinis kepada 12 orang guru BK binaan pada SMA Negeri di Kabupaten Buleleng. Pelaksanaan kegiatan supervisi klinis dilakukan sesuai jadwal yang telah disusun dan disepakati bersama yaitu dimulai tanggal 1 Agustus 2019 sampai dengan 16 Agustus 2019. Pelaksanaan kegiatan pertemuan awal kepada guru-guru BK yang bertugas di wilayah tengah dan timur (SMA Negeri 1 Tejakula, SMA Negeri 2 Tejakula, SMA Negeri 1 Kubutambahan, SMA Negeri 1 Sawan dan SMA Negeri 1 Sukasada) berkumpul pada hari Kamis, 1 Agustus 2019 bertempat di SMA Negeri 1 Sawan. Sedangkan pelaksanaan kegiatan pertemuan awal kepada guru-guru BK yang bertugas di wilayah barat (SMA Negeri 1 Banjar, SMA Negeri 2 Banjar, SMA Negeri 1 Seririt, SMA Negeri 1 Busungbiu, SMA Negeri 2 Busungbiu, SMA Negeri 1 Gerokgak, dan SMA Negeri 2 Gerokgak), berkumpul pada hari Jum'at, 2 Agustus 2019 bertempat di SMA Negeri 1 Seririt. Lebih kurang 60 menit guru-guru diberikan arahan dan diajak berdiskusi terkait persiapan pelaksanaan layanan bimbingan klasikal. Mulai dari RPL klasikal yang inovatif, jadwal pelaksanaan, hingga pembahasan instrumen yang akan dipergunakan pada saat observasi kelas.

Sesuai rencana, pelaksanaan kegiatan observasi kelas dan kegiatan pertemuan balikan dilaksanakan di sekolah masing-masing, dimulai tanggal 3 Agustus 2019 sampai dengan tanggal 16 Agustus 2019. Kegiatan observasi kelas dilakukan pencatatan segala bentuk kegiatan guru dan peserta didik yang nantinya dipergunakan memberikan skor pada instrumen penilaian. Sedangkan pertemuan balikan dilakukan melalui wawancara untuk melengkapi data penelitian. Peneliti menanyakan tentang perasaan guru BK dalam

(Meningkatkan Kemampuan Guru BK SMA dalam Pelaksanaan LayananBimbingan Klasikal Melalui Supervisi Klinis) 
pembimbingan yang telah berlangsung, target yang sudah tercapai, dan penyampaian catatan hasil pengamatan peneliti.

Berdasarkan data yang telah terkumpul, selanjutnya dilakukan refleksi yaitu mengkaji secara menyeluruh terhadap tindakan yang telah dilakukan, mencari kekurangan-kekurangan terhadap tindakan yang dilakukan termasuk membuat analisis, sintesis serta penilaian guna menyempurnakan tindakan. Hasil penilaian kemampuan guru BK dalam melaksanakan layanan bimbingan klasikal pada siklus I ditemukan 6 orang guru $(50,00 \%)$ mendapat nilai 61 - 75 (kategori cukup), dan 6 orang guru (50,00\%) mendapat nilai 76 - 90 (kategori baik) dengan nilai rata-rata 77,68 (kategori baik). Hasil penelitian tersebut dapat dilihat secara ringkas pada tabel 3 .

Melihat data tersebut menunjukkan bahwa belum tercapainya indikator kinerja yang telah ditetapkan, maka dalam penelitian tindakan ini peneliti mengumpulkan kembali guru-guru BK dalam kegiatan pertemuan awal kepada guru-guru BK yang bertugas di wilayah tengah dan timur (SMA Negeri 1 Tejakula, SMA Negeri 2 Tejakula, SMA Negeri 1 Kubutambahan, SMA Negeri 1 Sawan dan SMA Negeri 1 Sukasada) pada hari Senin, 9 September 2019 bertempat di SMA Negeri 1 Sawan. Sedangkan pelaksanaan kegiatan pertemuan awal kepada guru-guru BK yang bertugas di wilayah barat (SMA Negeri 1 Banjar, SMA Negeri 2 Banjar, SMA Negeri 1 Seririt, SMA Negeri 1 Busungbiu, SMA Negeri 2 Busungbiu, SMA Negeri 1 Gerokgak, dan SMA Negeri 2 Gerokgak), berkumpul pada hari Selasa, 10 September 2019 bertempat di SMA Negeri 1 Seririt. Pada kegiatan pertemuan awal siklus II, guru-guru BK diberikan bimbinganbimbingan/arahan dengan memberikan penekanan-penekanan pada aspek-aspek/ indikator tertentu yang belum terpenuhi pada kegiatan siklus I baik terkait perencanaan atau RPL inovatif maupun dalam pelaksanaan layanan bimbingan klasikal. Pertemuan awal ditutup dengan menentukan jadwal observasi di kelas sesuai dengan kesiapan dari guru tersebut.

Tabel 3. <Perolehan Nilai Kemampuan Guru BK dalam melaksanakan Layanan Bimbingan Klasikal Pada Siklus I>

\begin{tabular}{|c|c|c|c|c|}
\hline No & Nama Guru BK & $\begin{array}{l}\text { Perolehan } \\
\text { Kuantitatif }\end{array}$ & Nilai & Klasifikasi \\
\hline 1 & NKNY & 75 & & Cukup \\
\hline 2 & NKJA & 79 & & Baik \\
\hline 3 & KJS & 86 & & Baik \\
\hline 4 & NS & 79 & & Baik \\
\hline 5 & KS & 82 & & Baik \\
\hline 6 & $\mathrm{KNH}$ & 75 & & Cukup \\
\hline 7 & INT & 75 & & Cukup \\
\hline 8 & NPK & 71 & & Cukup \\
\hline 9 & NKSA & 82 & & Baik \\
\hline 10 & NKAY & 75 & & Cukup \\
\hline 11 & IKS & 75 & & Baik \\
\hline \multirow[t]{3}{*}{12} & WR & 79 & & Cukup \\
\hline & Jumlah & 932 & & \\
\hline & Rata-rata & 77,68 & & Baik \\
\hline
\end{tabular}

Pelaksanaan kegiatan observasi kelas dan kegiatan pertemuan balikan dilaksanakan di sekolah masingmasing, dimulai tanggal 11 September 2019 sampai dengan tanggal 24 September 2019. Observasi kelas dilakukan pencatatan mendetail tentang gerak-gerik guru yang bertalian dengan kelemahan guru yang sedang diperbaiki, pencatatan kegiatan peserta didik dalam mengikuti proses pembimbingan. Catatan ini nantinya dipergunakan untuk memberikan skor pada lembar instrumen penilaian layanan klasikal. Sedangkan pertemuan balikan dilakukan melalui wawancara untuk melengkapi data penelitian. Peneliti menanyakan tentang perasaan guru BK dalam pembimbingan yang telah berlangsung, target yang sudah tercapai, dan penyampaian catatan hasil pengamatan peneliti. 
Tabel 4. <Perolehan Nilai Kemampuan Guru BK dalam melaksanakan Layanan Bimbingan Klasikal Pada Siklus II>

\begin{tabular}{llll}
\hline No & Nama Guru BK & Perolehan Nilai Kuantitatif & Klasifikasi \\
$\mathbf{1}$ & NKNY & 86 & Baik \\
$\mathbf{2}$ & NKJA & 86 & Baik \\
$\mathbf{3}$ & KJS & 93 & Amat Baik \\
$\mathbf{4}$ & NS & 86 & Baik \\
$\mathbf{5}$ & KS & 86 & Baik \\
$\mathbf{6}$ & KNH & 86 & Baik \\
$\mathbf{7}$ & INT & 82 & Baik \\
$\mathbf{8}$ & NPK & 82 & Baik \\
$\mathbf{9}$ & NKSA & 86 & Baik \\
$\mathbf{1 0}$ & NKAY & 86 & Baik \\
$\mathbf{1 1}$ & IKS & 82 & Baik \\
$\mathbf{1 2}$ & WR & 86 & Baik \\
& Jumlah & $\mathbf{1 0 2 5}$ & \\
& Rata-rata & $\mathbf{8 5 , 4 2}$ & Baik \\
\hline
\end{tabular}

Berdasarkan data yang telah terkumpul, selanjutnya dilakukan refleksi yaitu mengkaji secara menyeluruh terhadap tindakan yang telah dilakukan, mencari kekurangan-kekurangan terhadap tindakan yang dilakukan termasuk membuat analisis, sintesis serta penilaian guna menyempurnakan tindakan. Hasil penilaian kemampuan guru BK dalam melaksanakan layanan bimbingan klasikal pada siklus II ditemukan 11 orang guru (91,67\%) mendapat nilai 76 - 90 (kategori baik), dan 1 orang guru (8,33\%) mendapat nilai 91 - 100 (kategori amat baik) dengan nilai rata-rata 85,42 (kategori baik). Hasil penelitian tersebut dapat dilihat secara ringkas pada tabel 4 .

Melihat hasil refleksi tersebut menunjukkan bahwa penelitian tindakan ini telah memenuhi indikator keberhasilan yang telah ditetapkan yaitu $100 \%$ guru BK memperoleh nilai kategori Baik (76 - 90) dengan nilai rata-rata sekurang-kurangnya 85 (kategori Baik).

Berdasarkan hasil penilaian yang diperoleh pada siklus I dan siklus II telah terjadi peningkatan nilai ratarata yang semula 59,52 meningkat menjadi 77,68 (30,51\%) pada siklus I, dan pada siklus II meningkat menjadi 85,42 (9,97\%) dari siklus I. Dari data tersebut dapat disampaikan bahwa upaya yang giat dilaksanakan guru BK bersama peneliti untuk meningkatkan kemampuan guru BK SMA Negeri di Kabupaten Buleleng dalam melaksanakan layanan bimbingan klasikal melalui supervisi klinis sudah dapat mencapai hasil sesuai harapan.

Keunggulan model supervisi klinis dalam upaya meningkatkan kemampuan guru, telah dibuktikan oleh beberapa peneliti diantaranya: 1) Hasil penelitian Amani, dkk. (2013) yang berjudul "Implementasi Supervisi Klinis dalam Rangka Meningkatkan Kemampuan Guru Mengelola Proses Pembelajaran pada Guru SD seGugus VII Kecamatan Sawan” diperoleh hasil, yaitu pada siklus I sebesar 75,83\% yang tergolong baik, meningkat pada siklus II menjadi 97,38\% yang tergolong sangat baik. Penerapan supervisi klinis dapat meningkatkan kemampuan guru IPS SD Gugus VII Kecamatan Sawan dalam melaksanakan proses pembelajaran. 2) Hasil penelitian Tanama Yulia Jayanti, dkk. (2016) yang berjudul "Implementasi Supervisi Klinis dalam Meningkatkan Profesionalisme Guru" menunjukkan bahwa implementasi supervisi klinis yang dilaksanakan dalam tiga tahap yaitu tahap perencanaan, tahap pelaksanaan, dan tahap umpan balik telah berjalan dengan baik dan dapat meningkatkan profesionalisme guru. 


\section{Simpulan}

Kemampuan guru BK SMA Negeri di Kabupaten Buleleng dalam melaksanakan layanan bimbingan klasikal perlu ditingkatkan. Untuk meningkatkan kemampuan guru BK melaksanakan layanan bimbingan klasikal, dapat dibantu melalui supervisi klinis. Cara yang dilakukan melalui tiga tahap yaitu tahap pertemuan awal, tahap observasi kelas, dan tahap pertemuan balikan. Pada tahap pertemuan awal dilakukan diskusi hasil refleksi terkait perencanaan maupun pelaksanaan proses pembimbingan di kelas. Sedangkan pada tahap observasi kelas, dilakukan pengamatan terhadap implementasi dari perencanaan yang telah dibuat. Kemudian pada tahap pertemuan balikan, guru BK diajak untuk merefleksi hasil kegiatan yang telah dilaksanakan. Masukan-masukan, saran-saran, pendapat-pendapat yang telah disampaikan di setiap siklus bertujuan untuk memperbaiki kekurangan, kelemahan demi tercapainya tujuan penelitian ini.

Hasil yang diperoleh dari penelitian ini menyatakan bahwa perolehan nilai kemampuan awal guru dalam melaksanakan layanan bimbingan klasikal diperoleh rata-rata 59,52 (kategori sedang) menjadi 77,68 (kategori baik) di siklus I, dan meningkat menjadi 85,42 (kategori baik) di siklus II. Dari data tersebut dapat diambil kesimpulan bahwa supervisi klinis dapat meningkatkan kemampuan guru BK SMA Negeri di Kabupaten Buleleng dalam melaksanakan layanan bimbingan klasikal.

\section{Saran}

Berdasarkan temuan dari hasil penelitian, dapat disampaikan beberapa saran yakni (1) Kepala sekolah sebagai supervisor hendaknya melakukan supervisi klinis secara rutin sehingga permasalahan yang terjadi dalam proses belajar mengajar atau pembimbingan dapat teratasi, (2) Kepada guru BK dalam menyusun perencanaan dan melaksanakan layanan bimbingan klasikal hendaknya mempertimbangkan karakteristik peserta didiknya, sehingga peserta didik merasa senang, antusias dan yang terpenting tujuan layanan dapat tercapai, dan (3) Kepada peneliti lain yang ingin memverifikasi data hasil penelitian ini diharapkan melakukan penelitian yang sama guna melakukan pemeriksaan terhadap kebenaran hasil yang sudah didapatkan.

\section{Ucapan Terimakasih}

Kami ucapkan terimakasih kepada pihak-pihak yang membantu selama proses penelitian hingga penyusunan artikel selesai.

\section{Refrensi}

Amani Luh, dkk. 2013. Implementasi Supervisi Klinis dalam Rangka Meningkatkan Kemampuan Guru Mengelola Proses Pembelajaran Pada Guru SD se-Gugus VII Kecamatan Sawan. e-Journal Program Pascasarjana Universitas Pendidikan Ganesha Jurusan Pendidikan Dasar, Volume 3 Tahun 2013.

Arikunto, Suharsimi. Suhardjono, Supardi. (2006). Penelitian Tindakan Kelas. Jakarta: PT. Bumi Aksara.

Danim dan Khairil. 2011. Profesi Kependidikan. Bandung: Alfabeta.

Depdiknas. 2008. Metode dan Teknik Supervisi. Jakarta: Direktorat Jenderal Peningkatan Mutu Pendidik dan Tenaga Kependidikan Departemen Pendidikan Nasional.

Jayanti, Tanama Yulia. dkk. 2016. Implementasi Supervisi Klinis dalam Meningkatkan Profesionalisme Guru. Jurnal Pendidikan: Teori, Penelitian, dan Pengembangan, Volume: 1 Nomor: 11 Bulan November Tahun 2016.

Masaong, Abd. Kadim. 2013. Supervisi Pembelajaran dan Pengembangan Kapasitas Guru Memberdayakan Pengawas sebagai Gurunya Guru. Bandung: AlFabeta.

Peraturan Menteri Pendidikan Nasional RI Nomor 41 Tahun 2007 tentang Standar Proses untuk Satuan Pendidikan Dasar dan Menengah. Jakarta: Biro Hukum dan Organisasi Departemen Pendidikan Nasional.

Peraturan Menteri Pendidikan Nasional Republik Indonesia Nomor 12 Tahun 2007 tentang Standar Pengawas Sekolah/Madrasah. Jakarta: Biro Hukum dan Organisasi Departemen Pendidikan Nasional. 
Permendikbud No. 111 tahun 2014 tentang Bimbingan Konseling pada Pendidikan Dasar dan Pendidikan Menengah. Jakarta: Biro Hukum dan Organisasi Kementerian Pendidikan dan Kebudayaan.

Permenpan dan RB Nomor 16 Tahun 2009 tentang Jabatan Fungsional Guru dan Angka Kreditnya.

Rosidah, Ainur. 2017. Layanan Bimbingan Klasikal Untuk Meningkatkan Konsep Diri Siswa Underachiver.

Tersedia pada http://garuda.ristekbrin.go.id/documents/detail/511034 Jurnal Fokus Konseling STKIP Muhammadiyah Pringsewu, Vol 3, No 2 tahun 2017. Diunduh pada tanggal 8 Juli 2019.

Sahertian, P. A. 2008. Konsep Dasar dan Teknik Supervisi Pendidikan Dalam Rangka Pengembangan Sumber Daya Manusia. Jakarta: Rineka Cipta.

Suaidinmath. 2010. Supervisi Klinis: Konsep Dasar dan Prosedur Pelaksanaannya. Tersedia pada http://www.suaidinmath.wordpress.com. Diunduh pada tanggal 8 Juli 2019.

Undang-Undang RI Nomor 20 Tahun 2003 tentang Sistem Pendidikan Nasional. Jakarta: Deputi Menteri Sekretaris Negara Bidang Perundang-Undangan.

Usman, User. 1995. Menjadi guru BK Profesional. Bandung: PT.Remaja Rosdakarya.

\section{Article Information (Supplementary)}

Copyrights Holder: <Gusti Nyoman Astika $><2021>$ https://doi.org/10.xxxx/Xxxxx

Open Access Article I CC-BY Creative Commons Attribution 4.0 International License.

Word Count: 4295
Conflict of Interest Disclosures:

The authors declare that they have no significant competing financial, professional or personal interests that might have influenced the performance or presentation of the work described in this manuscript.

First Publication Right: JIBK Undiksha 